J.E. Hoare and Susan Pares eds. Korea: The Past and the Prevent:
Slected Papers from the Britsh Association for Korean Studies BAKS Papen
$\frac{\text { Series }}{\text { Global Orental. } 1991-2004} \cdot 20015$. Bo-91. Folkestone, Kent:
ISBN 1-901903-54-0.

- First published in BAKS 5, 1994: 23-38

\title{
6 Yanagi Sōetsu and Korean crafts within the Mingei movement
}

\author{
KIKUCHI YUKO
}

$\mathrm{T}$

his paper elucidates Yanagi Sōetsu's relationship with and views on Korean crafts from a historical perspective, ending with a critical analysis of his position. Firstly, I give a brief background to Yanagi and his involvement with Korea. In the second section, I outline Yanagi's view on Korean crafts, focussing on the ceramics of the Chosonn period; and thirdly I would like to outline various criticisms and evaluation problems arising from Yanagi's view of Korean crafts.

It is well known that Yanagi Sōetsu (1889-1961) was the theoretical leader of the Mingei (Japanese folkcrafts) movement, which started in the 1920s and flourished until Yanagi's death in 1961. Yanagi used Buddhist analogies and terminology to create a theory about what constituted supreme beauty and to set the standard of beauty for getemono (common household objects handmade by unknown craftsmen). Yanagi was one of the members of the Shirakaba ('White Birch') group, the school of writers who were all from Gakushūin, the Peers' school, in Tokyo. He also edited Shirakaba, a magazine published between 1910-23, which mainly introduced new Western ideas and fine art and which had a great impact on the intellectuals of the time.

The Mingei movement, following Yanagi's aesthetic theory, was developed further by well-known figures such as Hamada Shōji, Kawai Kanjirō, Tomimoto Kenkichi, Bernard Leach, Munakata Shikō and Serizawa Keisuke - craftsmen of the Mingei movement who tried to create new 'true crafts' following Yanagi's aesthetics. The Mingeikan (Japan Folk-Crafts Museum)* established in 1936 in Tokyo is the tangible legacy of the movement in Japan, and overseas, the Mingei aesthetic has become widely known through Bernard Leach and his book, The Unknown Craftsman (1972). However, the latter only contains points taken from the twenty-two volumes of Yanagi's collected works that Leach considered significant or was able to understand given that his knowledge of the Japanese language was limited.

* I have followed the English translations officially used by the Mingeikan for 'Mingeikan' and 'Mingei' in this article. 


\section{YANAGI'S INVOLVEMENT IN KOREA}

Yanagi's involvement with Korea was extremely significant in the development of the Mingei movement. The seeds of his interest were planted by the Asakawa brothers and by his first trip to Korea in 1916. The Asakawa brothers were often overshadowed by Yanagi's fame, but it is very important that their role be recognized. Asakawa Noritaka, who had lived in Korea since 1913, conducted some of the first research on Korean ceramics - particularly Chosonn ceramics - and he was to excavate 700 pottery sites between 1922 and 1946. As an enthusiastic reader of the magazine Shirakaba, Asakawa first visited Yanagi in 1914 at Abiko, a suburb of Tokyo, to see the sculptures by Rodin sent to the Shirakaba group as gifts. On that occasion Asakawa gave Yanagi a Chosŏn faceted jar of white porcelain decorated in underglaze blue in the 'autumn grass style', ${ }^{1}$ a design which sparked Yanagi's interest in Korean ceramics. When Yanagi travelled to Korea for the first time in 1916, he stayed with Noritaka's younger brother, Asakawa Takumi, himself a pioneer researcher into Korean ceramics and folkcrafts. Yanagi benefitted enormously from the brothers' first-hand knowledge of Korean ceramics and their fluency in the Korean language.

Yanagi's involvement in Korea was a mixture of art and politics. In 1919 he published his first article on Korea, 'Chōsenjin o omou', ${ }^{2}$ on the occasion of the March First movement, the first big protest against Japanese rule since Korea's annexation by Japan in 1910. In his 1920 article, 'Chōsen no tomo ni okuru sho', he expressed his empathy and affection for Koreans and Korean art. In the same year, his wife Kaneko, a singer specializing in operatic arias, organized four fund-raising concerts in Japan in order to give free concerts in Korea to show sympathy for the suffering of the Koreans. Bernard Leach went with them to Korea where they gave as many as four lectures and seven concerts; it is said that they were enthusiastically welcomed by the people. After the success of this trip, he and the Asakawa brothers developed a plan for a Korean Folkcrafts Museum. In 1921 Yanagi circulated a piece on the establishment of the museum, 'Chōsen minzoku bijutsukan no setsuritsu ni tsuite', and advertised in Shirakaba for funds for the Museum. He made three trips to Korea that year including those concerning the museum: in January he negotiated with Governor-General Saitö Makoto for rent-free use of the Kwanp'ung-ru ${ }^{3}$ building as the museum; in June with his wife, he organized eight fund-raising concerts and ten lectures; and in July the death of his younger sister, Chieko, who was married to Imamura Takeshi - a senior civil servant working for the colonial government in Seoul - caused him to make his third trip to Korea. He also organized the first exhibition of Choson crafts in Japan in May of that year and he, Asakawa Takumi, and other friends bought about 600 items for the museum collection. Then in December, he organized an exhibition, 'Reproduction of the masterpieces of Western art', in Seoul. In January 1922, he gave lectures and exhibitions on William Blake, introducing Western art to Koreans in order to raise their awareness of their identity as Asians through the appreciation of Western art. On this trip, he also re-negotiated with Governor-General Saito for the use of a larger building for the museum. 


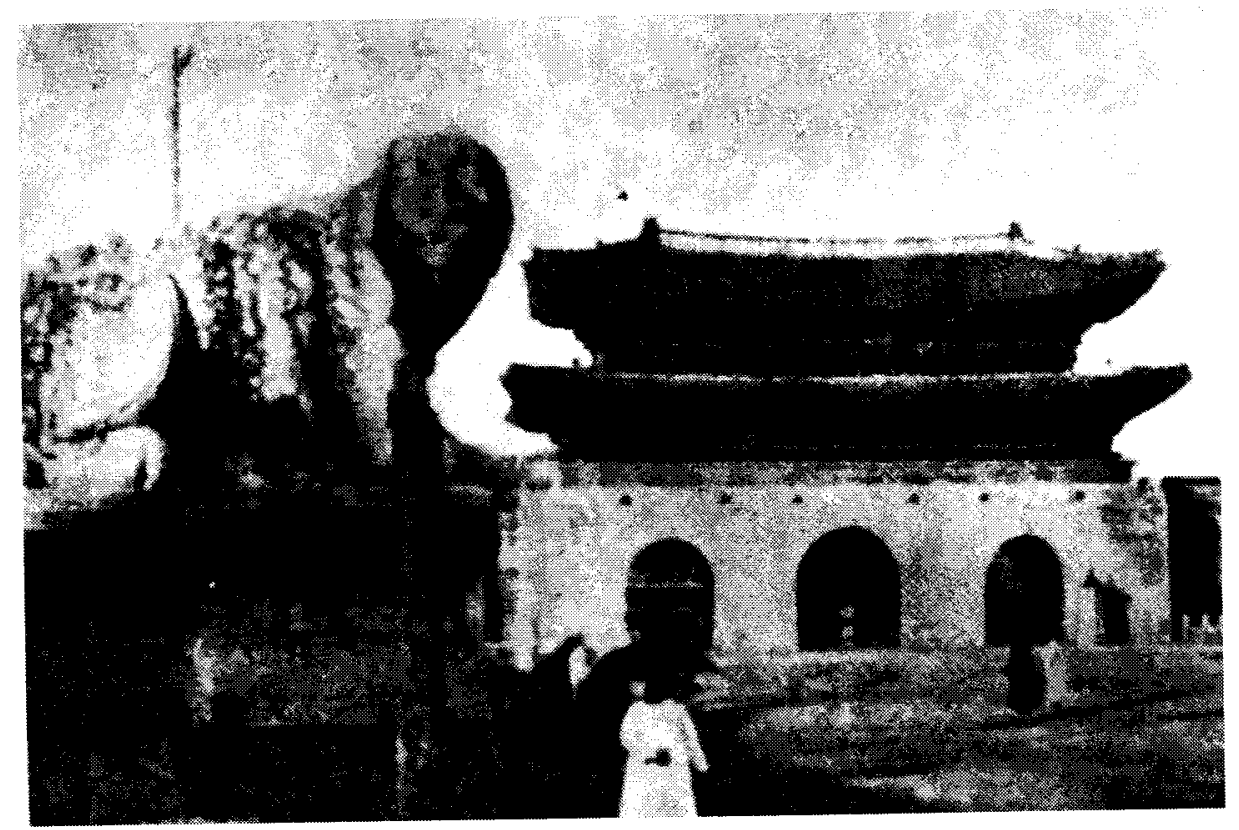

Fig.1. Kwanghwa-mun gate in Seoul, ca. 1922

Yanagi's ongoing interest in Korean ceramics took shape in 1921 as his first book on crafts, entitled Tojiki no bi. The ideas in this book contain the essence of his aesthetics, which developed into the Mingei theory. In 1922 he summarized his views on Korean art in 'Chōsen no bijutsu', and in the same period he published several political articles, which will be discussed below. In July 1922 , in response to the announcement of the proposed demolition of the Chosŏn-period Kwanghwa-mun (fig. 1), the front gate of the Kyonngbokkung Palace, and the construction in its place of a new Western-style building as the colonial government office, Yanagi published 'Ushinawaren to suru ichi Chōsen kenchiku no tameni'. This article is in the style of a lyrical poem personalising Kwanghwa-mun by calling it 'my dear' (omae) and likening its destruction to the murder of a human being. Partly as a result ofYanagi's passionate protest, Kwanghwa-mun was eventually saved. Also in 1922, Yanagi published $C h \overline{o s e n}$ to sono geijutsu, a compilation of his nine previous articles on Korea with royalties going to the Korean Folkcrafts Museum. An issue of Shirakaba featured Chosŏn ceramics as part of Yanagi's efforts to build the reputation of Chosŏn ceramics, which had largely been ignored up to that point.

As the first event under the name of the Korean Folkcrafts Museum, Yanagi, the Asakawa brothers and Tomimoto organized an exhibition in Seoul of Chosón ceramics, together with their academic research. Up to 1200 people, two-thirds of them Korean, visited this exhibition, which featured more than 400 items. In 1923 when the Great Kantō Earthquake occurred, a number of Koreans were killed because there were rumours circulated that 
they were planning to riot. Yanagi expressed his anger in a letter in English to Bernard Leach, saying ' $[\mathrm{sic}]$ Great massacre of Korean people happened together with the disaster was one of the most ignorant $\&$ biggest crimes we have done towards them' (Zensh $\bar{u} 21$, upper vol.: 617$){ }^{4}$ Then Yanagi gave fund-raising lectures in Seoul for humanitarian aid to the Koreans in Japan. In 1924 the Korean Folkcrafts Museum was officially opened at Chipkyŏngdang in the Kyŏngbok-kung Palace. With the opening of the Museum, four concerts were organized by Kaneko. It is said that two exhibitions a year were organized in spring and autumn after the Museum opened, and lecture and concert tours were organized almost every year, including aid concerts in 1925 for Korean flood disaster victims (Takasaki, 1979:84, 1991:104), until Asakawa Takumi's death in $1931 .^{5}$

With the publication in 1928 of Kögei no michi, the bible of Mingei theory, Yanagi became more and more involved in Japanese folkcrafts, but still he visited Korea almost every year. 1932 saw the publication of a special issue of Koggei ('Crafts') on Korean ceramics; and the exhibition and sale of several thousand items of contemporary Korean folkcrafts was organised in Tokyo and Kyoto. After the Second World War, and in particular from 1950 on, Yanagi published many articles on various Korean crafts other than pottery ranging from sculpture, woodwork and metalwork to paintings, etc. As he developed his 'Buddhist aesthetics', he began to apply these to Korean crafts, too. By 1940, Yanagi had travelled to Korea twenty-one times. In that year he made his last trip with Hamada Shōji, Kawai Kanjirō and Shikiba Ryüzaburō, though he continued to organize exhibitions of Korean folkcrafts and to write about Chosŏn ceramics and other crafts until his death in 1961.

\section{YANAGI'S VIEWS ON KOREAN CRAFTS}

Yanagi's approach to artefacts was generally by 'direct insight' (chokkan), ${ }^{6}$ and he tried to keep the background of the object in mind as he viewed it. His approach was initially derived from the 'new mystery' he wrote about in his 1914 letter, 'Abiko kara: tsüshin 1'; that is, the shape of a pot tells you more than just its shape. In his first systematic book on crafts, Tojiki no bi in 1921, he refined this insight into the idea that 'through the beauty of the pot you can understand the mind of the people, the culture of the period, its natural background and the relationship of the people and beauty' (Zensh $\bar{u} 12: 4$ ). Yanagi used the term, 'beauty of intimacy' (shitashisa no bi) for one's first level of analysis of the nature of specific beauty. Later in Mingei aesthetics, this beauty was categorized in finer detail as 'beauty of tradition, nature, functionality, simplicity, selflessness, plurality, inexpensiveness and health'.?

Yanagi applied this approach to objects to Korean art and summarized his views in the term, 'beauty of sadness' (hiai no bi). In Yanagi's first article on Korea, he wrote that the Koreans who had been 'violated and bullied' (shiitagerare ijimerareta) by the Japanese and Chinese invasions needed 'sympathy' (ninjo) and 'love' (ai), and this need reveals itself in

the beauty of line, which is characteristic of Korean art, and also symbolises the heart starving for love of the Koreans ... That beautiful long 


\section{PART 1: THE TRANSITION INTO THE MODERN PERIOD}

Korean line expresses exactly their starving hearts. Their grudges, their prayers, their wishes, their tears, all are felt in the flowing line ... The Koreans have expressed their 'sad feeling' [sabishii kimochi] and their starving for something in this beautiful, appealing, long and curved line. (Zenshü 6:27)

In this way, through the appreciation of one Korean pot, he developed what has been considered to be empathy for the Korean people and their culture.

The term 'beauty of sadness' (hiai no bi) appeared for the first time in his article of 1920, 'Chōsen no tomo ni okuru sho' (Zenshū 6:42-3):

The long, harsh and painful history of Korea is expressed in the hidden loneliness and sadness of their art. It always has a sad beauty and loneliness that brings you to tears. When I look at it, I can not control the emotion that fills my heart. Where else can I find such hiai no bi?

In his 1922 article on Korean art, 'Chōsen no bijutsu', Yanagi summarised his view of hiai no bi as the supreme beauty of Korean ceramics clearly and simply by comparing the art of three different cultures: the strong shape of Chinese ceramics, created by 'the practical and strong Chinese people' (shina no jissaiteki na kyokona minzoku), the colourful ceramics of the Japanese created by 'cheerful Japanese' (tanoshii nihonjin) and the sad and lonely line of Korean ceramics created by 'lonely Koreans' (sabishii Chōsen minzoku). He saw this 'Korean line' everywhere in Korea, in architecture, sculpture, paintings, nature, crafts and particularly in ceramics (Zenshü 6:102):

[A liquor bottle] has a long and narrow shape and is not secure in balance, but the desire to express the line is fully satisfied. [Bowls] have small feet and serene lines form the sides. Sometime the foot is cut so that its balance is even less secure. They do not have the shape to sit firmly on the earth. This is the image of Korea, ... reminding us of their suffering and sad experiences.

Technique, firing and designs also reflect the sadness. The inlay method is 'passive and quiet with hidden beauty'. The reducing fire they use is 'smoky fire which they prefer to the bright, strong oxidising fire. They hide their face in the smoke and reveal their weeping souls' (Zensh $\bar{u}$ 6:103). Popular Koryŏ designs such as 'willow and ducks' and 'flying cranes and clouds' (fig. 2) are also sad.

There is nothing with such long, thin and beautiful lines as the willow. Under that sad willow, there is a stream of water and floating ducks. The water stream will never remain the same and the ducks can never stay in the same place. This is the very symbol of people living on a peninsula. Where else can you find more sad and beautiful designs ... the 'flying cranes and clouds' design represents one or two scattered lonely clouds in the vast air and a couple of cranes without any destination ... who fly away somewhere, their sad calls echoing once or twice in the high sky of sunset. They are cranes with long legs and thin feathers. I cannot help thinking about inevitable meanings hidden in those designs. (Zensh $\bar{u}$ 6:104-5)

In addition to 'lines' as a symbol of sadness, Yanagi pointed out the colour 'white' (fig. 3). The white clothes worn by Koreans - whether male or female, 


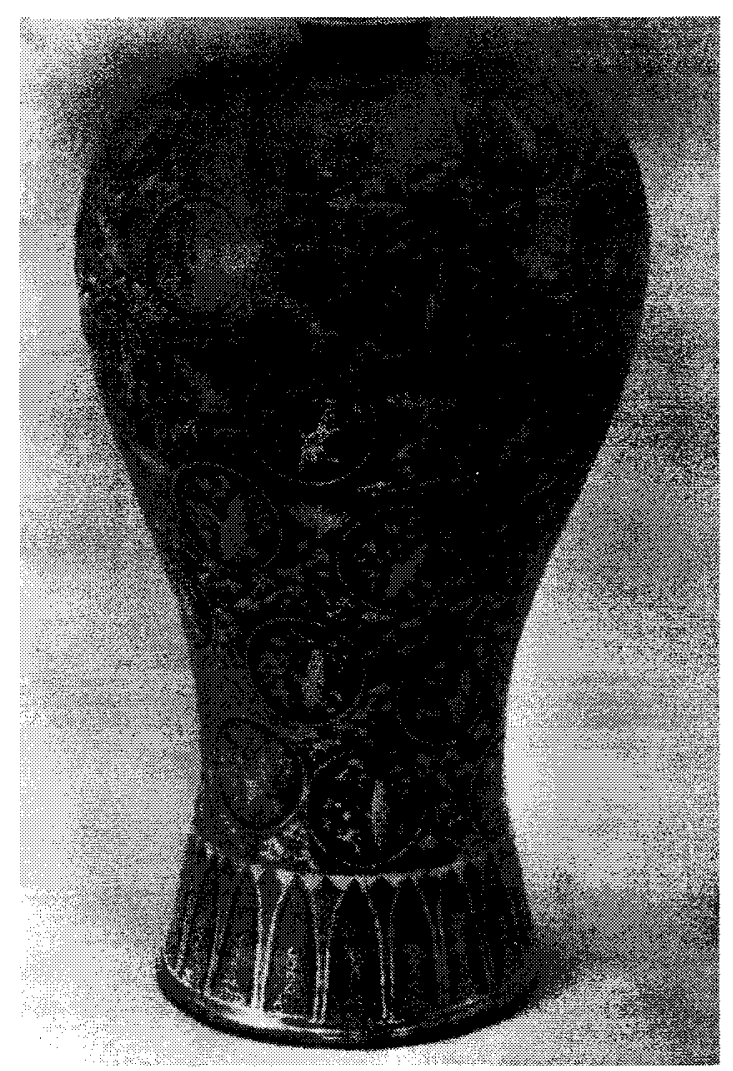

Fig. 2. Celadon-glazed porcelain maebyŏng vase with inlaid 'flying cranes and clouds' design. Koryŏ period, 12 th century; height $42 \mathrm{~cm}$

old or young - are '... mourning dresses. They are a symbol of their sad and humble minds. By wearing white clothes they are eternally in mourning" (Zensh $\bar{u}$ 6:105). Furthermore, he gave other examples such as the lack of variety in children's toys, the scarcity of flower vases, and 'the sadness of the music with its series of long notes which seem to sink and die away' (Zensh $\bar{u}$ 6:107). He concluded that 'Korean life generally lacks cheerfulness' (Zensh $\bar{u}$ 6:105).

Yanagi had an extremely sentimental and dogmatic idea of hiai no bi in Korean art and this idea continued more or less throughout his writings on Korean crafts until the end. However, there is a noticeable and gradual change in tone to a less sentimental one and a move to other perspectives.

The first noticeable change came in 1922 when Yanagi started to concentrate on re-evaluating and restoring the reputation of Chosŏn ceramics. In 'Richō tōjiki no tokushitsu' and 'Richō yōmanroku', published in Shirakaba, he dealt specifically with the characteristics of Chosŏn and Koryŏ wares rather than the characteristics of Korean ceramics as a whole. His interest in 


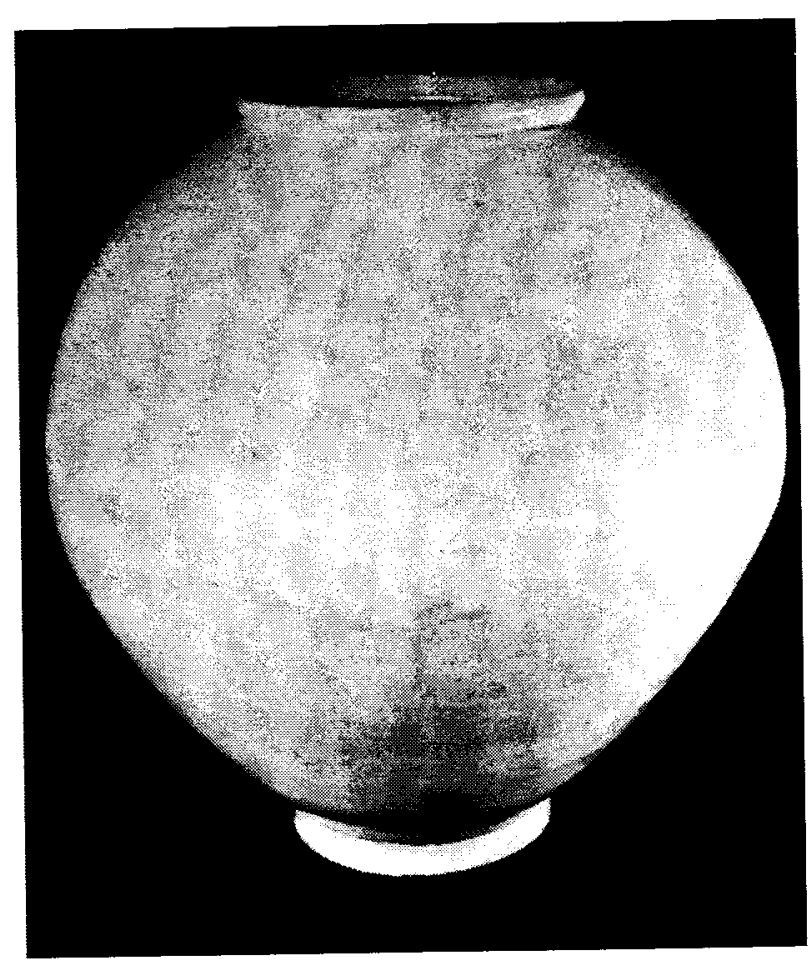

Fig. 3. Large white porcelain jar. Chosonn period, 17 th century; height $42.8 \mathrm{~cm}$, rim diameter $19.8 \mathrm{~cm}$

comparing the two wares continued in 'Kōrai to Richō'. He described Koryŏ ware as having 'feminine beauty' (josei no bi) and Chosŏn ware as having 'masculine beauty' (dansei no bi) (Zensh ü 6:159). Reflecting the changes of social belief in the Chosonn society from Buddhism to Confucianism, the characteristics of the ceramics also changed from 'beauty of delicacy' (sensai $n a y \bar{u} b i$ ) to 'beauty of will' (ishi no bi) and from sensitive forms and lines to simple, strong and big shapes (Zensh $\bar{u}$ 6:158). But Yanagi also added that although Chosonn ware has strength, it is not the same strength as that of Chinese ceramics. The typical Chosŏn white porcelain jar has

... a wide shoulder which can not be seen in Koryŏ ware but when you look at the way it tapers to the bottom and its small foot, it is a 'sad figure' [sabishii sugata] different from the strength and pride of Chinese ceramics ... The white colour is also different from the white of Ming Ware. [The Chosorn whites] are always either pale blue-tinged white, powdery white or dull greyish white. (Zenshü 6:161)

He later concluded that 'such warm whites can not be seen anywhere else $\ldots$ and plain white is the ultimate state of beauty' (Zensh $\bar{u} 6: 363$ ). However, in these two articles, he no longer strongly emphasizes hiai no bi. His emphasis 
has shifted, rather, to 'unquestioning trust' (mushin na shinrai) in Nature or 'the truth hidden between the mind of the craftsman and Nature' (Zensh $\bar{u}$ 6:165) and 'naturalness without "intention"' (sakui) (Zenshy 6:187) as the special character of Chosŏn ware. In the special issue of Kōgei on Chosŏn ceramics in 1932, Yanagi's aesthetic of beauty developed terms used for the appreciation of ordinary household crafts - moving from 'naturalness' (shizensa) to 'anonymity' (mumei), 'functionality' (jitsuyo), and 'health' $(k e n k \bar{o})$ to explain the essence of Choson ceramics. These elements were summarized again more systematically in 'Richō tōji no nanafushigi', published in 1959.

The second change in Yanagi's writings came after the Second World War, especially from the 1950s onwards in articles such as 'Chōsen jawan', 'Richō tōji no bi to sono seishitsu' and 'Richō tōji no nanafushigi'. It was during this period that Yanagi developed his Buddhist aesthetics on crafts inspired by his friend and teacher, Suzuki Daisetsu. The Chosonn tea bowls, such as the one named Ido, ${ }^{8}$ which were highly prized by tea masters in Japan as early as the 16 th century, were ordinary rice bowls and were considered to have 'the truest beauty' (Zensh $\bar{u}$ 6:519). They were made by unknown craftsman with 'no intentional clever thought' (mushin) (Zenshü 6:519), relying on 'the way of other power' (tariki) (Zensh $\bar{u}$ 6:483). Yanagi concluded that the beauty of Chosŏn ceramics should be called 'beauty of unity' (funibi) (Zenshū 6:519). In these three articles Yanagi used 'naturalness' (shizensa) and 'freedom' (jiyüsa) to describe the image of Chosonn ceramics; no longer did he use terms such as 'sadness' (hiai) or 'loneliness' (sabishisa). He even concluded that the use of white, which he had analysed as the colour of sadness, was a 'reasonable solution to avoid complication of the design process for inexpensive ordinary folkcrafts' (Zensh $\bar{u}$ 6:537).

Yanagi's central view on Korean crafts - first summarized in the term 'beauty of sadness' (hiai no bi) as the specific quality of Korean crafts changed to 'beauty of naturalness' (shizensa no bi) and then eventually to 'beauty of unity' (funibi), which he applied to all crafts, not just to Korean ones.

\section{CRITICISM AND EVALUATION OF YANAGI'S VIEWS ON KOREAN ART}

There has been very little critical evaluation in Japan of Yanagi's views of Korean folkcrafts, with Takasaki Sōji and Idekawa Naoki being the only two critics to analyze and criticize Yanagi's work. The so-called critics of the Mingei-ha (the Mingei faction) - such as Mizuo Hiroshi, Shikiba Ryūzaburō, Tonomura Kichinosuke, Tanaka Toyotarō - were people who worked with and supported Yanagi in the promotion of the Mingei movement, writing numerous, uncritical articles adulating Yanagi and maintaining his high reputation. They praised Yanagi's criticism of the government as being, for that time, extremely brave, undaunted by the threat of censorship or by the police who monitored his actions. They admired his humanism and the deep insight into Korea that sprang from his sharp 'direct insight' (chokkan).

In 1961, the year Yanagi died, Ubukata Naokichi wrote the first article in 
Japan which evaluated Yanagi's view on Korea, rating favourably Yanagi's objection to the assimilation policy and his humanism under the difficult circumstances in Japan and noting that Yanagi's reputation was higher in Korea than at home. Tsurumi Shunsuke (1976), a leading scholar of intellectual history followed Ubukata's opinion, and it was not until Takasaki Sōji's article in 1979 that anyone criticized Yanagi's work from a Korean perspective or pointed out the perception gap between the two countries. Idekawa Naoki's work in 1988 analytically criticized Yanagi's Mingei theory and view of Korea, and he claimed that the beauty of sadness (hiai no bi) was totally under-theorized.

In Korea the situation was diametrically different. From 1961 until a peak in the 1970s, there were many articles on Yanagi; of the 16 major articles that I have found, 11 were negative. Critical articles were rather emotional in tone before Ch'oe Harim set up in 1974 the first model of criticism which dominated the rest. Back in 1922, Pak Chonghong had criticized Yanagi's theory of the 'beauty of sadness' (hiai no bi) as a prejudiced view, and in 1931 Ko Yusŏp declared it to be 'merely poetic' and under-theorized. Three articles (Kye 1961; Kim Huimyŏng 1961; anon. 1961) that positively evaluated Yanagi's involvement with Korea were published the year Yanagi died, and there was another article supporting Yanagi seven years later (Kim Ulhan 1968). But these are exceptions to the mainstream of opinion.

In $1968 \mathrm{Kim}$ Talsu, a Korean living in Japan, initiated the debate about Yanagi's view of white as the colour of sadness. Kim used historical examples to show that from the Korean perspective, white was the ultimate colour, showing humour and dynamism. This argument about the symbolism of colour was continued by Kim Yanggi $(1975,1977 a, b, c)$ and Lee Chinhŭi (1978). Ch'oe Harim's seminal work in 1974 established the concept of the 'aesthetics of colonialism'; it became a milestone for critics who followed. Although Ch'oe notes that Yanagi passionately impressed the Koreans in the 1920 s, he criticised Yanagi's view as being 'a mixture of imperialism, backed by the "Cultural Policy" applied by the colonial government, and sentimental humanism' and a 'superficial interpretation of Korean history'; he adds that the beauty of line is a general characteristic of Asia. He called on Koreans to re-examine Korean art history, free of the Japanese view of Korea during the period of Japanese rule (Ilche sidae), and other critics followed his lead (Lee Mannyŏl, 1974; Kim Yunsu, 1977; Mun Myŏndae, 1977). Then in 1989, Cho Sonmi summarized previous critical analyses of Yanagi's work, both from the point of view of his contributions and his weaknesses, and raised the key question about how to look at the art of another country.

As Takasaki Sōji indicated, there is an obvious perception gap between the two countries. But there is also the difficulty of how to evaluate Yanagi's work on Korea, given the unusual circumstances of the Japanese occupation. $\mathrm{He}$ certainly organized numerous concerts and lectures, both to show friendship and to raise funds for humanitarian aid, to pay for exhibitions of Korean folkcrafts and to build the Korean Folkcrafts Museum to preserve these works. These activities of his were acclaimed by the Koreans in 1920s. He was vehement too, in his denunciation of the immoral and inhuman behaviour of 
the Japanese towards the Koreans, castigating the brutality of the Japanese government as 'shame on shame' (chijoku no chijoku) for Japan (Zensh $\bar{u} 6: 38$ ).

Yanagi's political opinions, however, can be clearly seen as ambivalent in his five political articles which appeared in the early 1920s ('Sekika ni tsuite', 'Kenshō shōsetsu boshū ni tsuite', 'Hihyō: Arekisandaa Paueru "Nihon no Chōsen tōchi seisaku o hyōsu"', 'Nissen mondai no konnan ni tsuite', and 'Chōsen ni okeru kyōiku ni tsuite'). In these articles he denounced the Japanese government, advocating the abolition of Japanese militarism, the granting of absolute freedom of speech for the Koreans, the provision of higher education in Korea and the implementation of moral human discipline to attain peace. At the same time, he called on the Koreans to undertake self-reflection on their lack of 'self-awareness' (jikaku) and on the fact that they had not protected their own country, saying, "before dreaming of independence, dream of producing a great man of intellect, a great scientist and a great artist. Reduce the amount of time you complain and increase the time you study. Please do not abandon yourselves to despair' (Zenshü 6:186). Then he concluded that the best solution would be for both countries to compromise. Although he strongly denounced the Japanese government, it seems to me that in reality he was only against military rule, not against liberal rule to 'civilize' the Koreans. His limitation is that he did not question the justice or injustice of colonization itself.

The prejudice of the Japanese, including intellectuals, towards the Korean people, is revealed in the stereotyped view that Koreans were not capable of governing themselves. It also reflects mainstream Western opinion as it was seen in the article by Alexander Powel1 ${ }^{9}$ (1922), justifying power politics as inevitable in order for civilized nations to civilize the primitive ones in the competition for colonies. Although Yanagi had high morals, being a product of the period of modernization in which Japanese intellectuals suffered from a massive sense of inferiority towards the West, he could not help but follow the Western model. His paternalistic stance also has parallels with the attitudes of Lafcadio Hearn and Bernard Leach, whom he idealised (Zenshī 6:24).

Yanagi himself was in a difficult position. Some of his articles were censored when published, and he was closely followed and watched by the police as a 'dangerous person'. Yet at the same time, he sometimes defended the offcials of the colonial government. 'I know Japanese greedy merchants and arrogant policemen have made the problem more difficult, but the officials in the colonial government do not want violence. There are many intellectuals among them and they are trying to govern justly' (Zensh $\bar{u}$ 6:228). This attitude was possibly a result of Yanagi's strong personal and family connections. The colonial Governor-General Saitō Makoto was junior (kōhai) to Yanagi Narayoshi, Sōetsu's father, himself a navy rear admiral and a mathematician; and Saitō also knew Sōetsu's older brother-in-law, Katō Motoshirō, former consul-general at Inch'on during the Russo-Japanese War in 1904. He also knew Yanagi's younger brother-in-law, Imamura Takeshi, who was a senior civil servant in the colonial government. Therefore, whether he was aware of it or not, Yanagi may have been used by Saitō as part of his 'Cultural Policy' (bunka seiji) from 1919 to 1931, which tried to demonstrate a general 
relaxation of controls over Korean people's cultural and political life so as to change the negative image of the colonial government aggravated by the harsh repressive rule of previous governors-general.

\section{CONCLUSION}

Yanagi's involvement with Korea played a vital part in the development of the Mingei movement and its aesthetic, as it was through the process of theorizing the beauty of Korean crafts that he acquired an articulate aesthetic language. However Yanagi's central view on Korean crafts, as summarized in the term, 'beauty of sadness' (hiai no bi), has been clearly shown to be extremely sentimental and dogmatic in the light of the perception gap revealed between Japan and Korea in the subsequent evaluation of Yanagi's views on Korean crafts.

Art criticism is a synthetic product of historical, political and cultural factors, and Yanagi's approach to Korean crafts reveals how strongly he was influenced by the times in which he lived. Although his views shifted slightly in time from hiai no bi to more universal values for appreciating crafts, Yanagi's initial views of Korea were coloured by exoticism under Japanese colonization, just as European evaluation of the art of Asia, the Near and Middle East and Africa is dazzled by exoticism. Through studying Yanagi's work one can see both the danger of perceiving the art of another country as distorted by one's own cultural perspective and the difficulty of building a balanced perception.

Evaluation of Yanagi's genuine help to Koreans and Korean crafts should remain high and positive as ever, but at the same time, Yanagi's aesthetic views on Korean crafts and his theory need further re-evaluation: on the Korean side, in the context of factual studies of Korean social and economic history, and on the Japanese side, in the context of Japanese modernization as Japan encountered the West. In the West, major art books on Korean art, such as those by Gompertz $(1964,1968)$, should be used with caution because of the undue influence of Yanagi and the Mingei-ha.

\section{ACKNOWLEDGMENTS}

I would like to express my special thanks to Sue Preston of the University of Sheffield for correcting my English writing and for various other suggestions; to Kim Hyejŏng of Tokyo National University of Fine Arts and Music for translation of articles from Korean to Japanese; and to Visiting Professor Kim Yong-suk from Kyŏngsang University for romanization of Korean words.

Credits for the illustrations are due to the Japan Folk-Crafts Museum (fig. 1) and the National Museum of Korea (figs 2-3).

\section{NOTES}

1. Chosón blue-and-white porcelain pots were highly valued in Japan; they are decorated with flower and plant designs widely known as the 'autumn grass style' (akiktisade) - a term which Yanagi coined in his article 'Kögei bunka' (Yanagi 1954b, 3: 336). Idekawa Naoki argued that the kinds of flowers 


\section{KOREAN CRAFTS WITHIN THE MINGEI MOVEMENT}

and the plants used for this design need not necessarily be autumn ones because spring and summer plants such as plums, orchids and irises were also seen mixed with the autumn plants. Yanagi, however, deliberately used the term akikusa to emphasise the sad feeling and the 'beauty of sadness' he perceived to be characteristics of Chosón pottery (see Idekawa 1988: 159-62).

2. Yanagi's works mentioned in the text are listed in alphabetical order, with their English translations and dates of publication, under Yanagi 1981 in the list of references for this article.

3. This building used to exist outside the north gate of the Kyongbok-kung Palace.

4. Yanagi's writings are cited in the text as printed in his collected Zenshü. This 22 -volume series is listed in the references as Yanagi 1981.

5. After Asakawa Takumits death in 1931, this museum was mostly closed to the public and opened to a few occasional visitors. The key of the muscum was kept by Asakawa Noritaka, and the muscum was maintained by Yanagi's and Asakawa's friends in Seoul. During the Second World War, the collection of the museum was moved to Kunjŏngjon from Chipkyong-dang, then to Minjok Pangmulgwan (Folklore Museum), and finally the collections were absorbed into the collection in Kungnip Chung'ang Pangmulgwan (National Museum of Korea) after the war (Takasaki 1991: 107).

6. There are several English translations of chokkan such as 'intuition' (Yanagi 1954); 'the sceing cye' (Leach 1972); and 'direct perception' (Moeran 1984).

7. Yanagi's terminology describes elements of ideal beauty in the 'true crafts' made by hand by unknown craftsmen without ego, frec from the desire to be famous or rich, mercly working to earn their daily bread. 'True crafts' are made from natural materials using traditional methods: characteristically of simple form strong enough to be functional and of simple design not artistically decorated, which are copied and produced in large quantities, in expensively. Yanagi describes the combination of all of these elements as 'healthy'.

8. There are several opinions about the derivation of the name Ido: (1) Mr Ido of the Yamato region owned this bowl; (2) Mr Ido, the governor ofWakasa region, owned the bowl; (3) the name was taken from the shape of the bowl, which is exceptionally deep - as deep as an ido ('well'); (4) from the place name, Ido, in Kyoungsan province, Korea, whence this bowl came.

9. Alexander Powell (1879-1957) was a political analyst and a political editor specialising in foreign affairs for several newspapers and magazines in the USA and Britain.

Editor's note (April 2006): Dr Kikuchi's paper is reprinted here with small amendments. The Japan rolk-Crafts Muscum has again kindly permitted the reproduction of fig. 1 . Application has been made to the National Museum of Korea for permission to reproduce figs 2 and 3 again. 